\title{
Forgiveness speech as a image restoration strategy: Accounts of King Juan Carlos I
}

\section{Barkamena, izen ona berreskuratzeko estrategia: Juan Carlos erregearen kasua}

\section{El perdón como estrategia de restauración de la imagen: el caso del rey Juan Carlos}

\section{Julio César Herrero' J. Pedro Marfil Medina²}

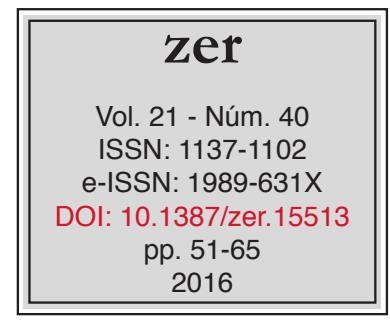

Recibido el 17 de febrero de 2015, aceptado el 13 de enero de 2016.

\begin{abstract}
In 2012, Juan Carlos I suffered an accident in Botswana while he was in a hunt. It had grave repercussions in terms of Spanish public opinion towards the Monarchy. This work develops an approach to forgiveness speech focusing on several theories and works and an analysis of speech of Juan Carlos I, following the William Benoit theory about image restoration. We can conclude the positive result of the king's speech in order to stop the media fuss and keep the crown reputation and its influence in future image restoration strategies in Spanish political parties.
\end{abstract}

Keywords: Forgiveness, speech, politics communication, Spain.

\section{Laburpena}

2012an, Juan Carlos I.ak istripua izan zuen Botswanan, ehizean zebilela. Gertakari horrek oihartzun handia izan zuen espainiarren iritzi publikoan eta monarkiari buruz zuten irudian. Lan honetan, gertuagotik aztertu dugu barkamenaren diskurtsoa, eta Juan Carlos I.ak bere barkamenean erabili zituen hitzei erreparatu diegu, William Benoiten izen ona berreskuratzeko teoriari jarraikiz. Lanaren ondorio nagusia da hitzaldiak balio izan zuela komunikabideen zurrunbiloa geldiarazteko eta koroaren izen onari eusteko. Horrez gain, baliteke horrek eragina izatea Espainiako alderdi politikoek euren izen ona garbitzeko erabilitako estrategiekin.

Gako-hitzak: Diskurtsoa, barkamena, komunikazio politikoa, Espainia.

\footnotetext{
Universidad de Alcalá, jc.herrero@uah.es

2 Universidad Camilo José Cela, jpmarfil@ucjc.edu
} 


\section{Resumen}

Juan Carlos I sufrió un accidente en Botsuana en 2012 mientras estaba de cacería. El suceso tuvo un gran impacto en la opinión pública española y en la percepción de la monarquía. Este trabajo desarrolla una aproximación al discurso del perdón y un análisis de las palabras de Juan Carlos I en su disculpa, siguiendo la teoría de restauración de la imagen de William Benoit. El trabajo concluye que el discurso contribuyó a detener la vorágine mediática y a mantener la reputación de la corona y su posible influencia en las estrategias de restauración de imagen de los partidos españoles.

Palabras clave: Discurso, perdón, comunicación política, España. 


\section{Introduction}

To say 'I am sorry' according to usual custom in society can be a sign of consideration and good manners. This is particularly clear in the cases in which the person who apologizes is a politician or a public figure. Apologizing can be a turning point in communicative process.

A message asking for forgiveness can become a helpful tool in order to overcome a communication crisis or attack, which places into question the image projected to the public. This article aims to make an approach to forgiveness speech in politics as a image restoration strategy having in consideration several theories and works from previous authors. The main hypothesis is that forgiveness speech is a useful strategy to keep a good image according to new leadership models.

An apology brings the chance to go beyond the offensive act and restore the relationship between actors through communication. I also have the ability to restore what we might call 'communication initiative' to the wrongdoer. By asking for forgiveness, the actor changes from a passive subject, who receives criticism for his/her acts, to an active subject, a person asking for forgiveness from the victim.

This work will frame these afore mentioned arguments within the context of the Botswana affaire surrounding the former King Juan Carlos I. The work will demonstrate the hypothesis that the King's words after the Botswana accident had a positive effect in taming the managerial crisis, which he was in. Moreover, this public mea culpa was effective in stopping the negative media commotion and the damage to his public image. We aim to make a qualitative approach to the issue showing it's background and utility.

\section{Method}

This work presents different methodologies. First, it develops an approximation to accountability and forgiveness speech as image restoration strategy in former works of authors like Schönbach (1980), Abadi (1990), Ryan (1982) and specially, Benoit $(1995,1997)$, who developed a detailed work from previous literature and suggested a useful theory of image restoration strategy (Benoit, 1995). We will also consider the influence of communication crisis management in this contexts.

This paper will work with content analysis. In the case of accounts regarding King Juan Carlos I after his Botswana accident, the work will analyse the king's words in order to understand what he wanted to project to his audience and as well the texts published in the most widely-read newspapers in Spain: El País (politically center-left), and $\mathrm{El} \mathrm{Mundo}$ (politically center-right).

The present paper is based on Benoit $(1995,1997)$ works, in which he analysed the rhetorical sources and the media impact of the selected strategy in order to restore the damaged image. As Benoit (1995: 143-157) did with cases as president Nixon Cambodia's Adress we analyse briefly the king's mortification and his words from a rhetorical point of view.

In order to value the king's speech impact public valuation, we will use both bibliographic and hemerographic fonts. We will also make a brief analysis of the public valuation of the monarch's words through an opinion pool published in one 
of the most important Spanish medias a few days later. This work will also consider the columns in which different opinion leaders showed their valuation of the situation. Conscious that the global knowledge from public opinion is difficult, we consider that by analysing the medias, we can extract an interesting point of view of the events.

\section{Forgiveness speech as image restoration strategy}

To begun with, it's important to know that the forgiveness speech may be part of a crisis management. No one will apologize at least he may do. And that may occur in cases in witch he consider that he's suffering a reputation damage that is, a crisis context.

The forgiveness speech is a very huge and transverse field. Different knowledge areas like sociology, communication, rhetoric, psychology and politics meet on it. Because of that, it is a field, which concerns much more than political speech. It has to do with interpersonal relationship, social habits and culture.

According to Tucker et al. (2006: 195), apologies are critical in rebuilding and sustaining long-term relationships. In the same way, the authors affirm that their research underscores the powerful role that apologizing can play in positively influencing follower perceptions of leader (Tucker et al., 2006: 205). Gonzales et al. $(1990,1992)$ comment that concession is a useful behaviour in order to maintain status and save face. Thus, one might say that an egoistic component is introduced in the behaviour at the moment to apologize. According to that, we are motivated by personal factors, such as wanting to avoid losing our position and mitigate damage to our image, rather than the potential harm to interpersonal relationships.

The modern apology also stands traditional notions of prestige and power on their heads by giving priority to the concepts of justice and mercy, which end up becoming most crucial in reconciliation (Mills, 2001: 116). Thus, accounts may be viewed as verbal strategies designed to mitigate the tendency of witnesses to come to undesirable conclusions about the character or worth of actors who find themselves enmeshed in a predicament (Gonzales et al. 1990: 611).

Also, According Kruse, a person should "repair [his or her] character if it has been directly or indirectly damaged by accusations or rumours and allegations, which affected negatively to his behaviour or judge" (1977: 13).

We consider Benoit and his work about the image restoration strategies a good model to work with. His classification simplifies previous models that he looks over like Sykes and Matza (1957), Scott and Lyman (1968), Schönbach (1980), Schlenker (1980), Tedeschi and Reiss (1981); or Semin and Manstead (1983).

Like Schönbach (1980), William Benoit has categorized and classified different image restoration strategies (Benoit, 1995). Initially, the mortification stage tries to restore the image by apologizing for act (1997: 179). In this context, he differences several strategies for image restoration (1995: 75-79). Thus we find 'denials' where the speaker may deny performing the wrongful act; evading responsibility, where those who are unable to deny performing the act in question may be able to evade or reduce their apparent responsibility for it; reducing offensiveness, attempting to reduce the degree of ill feeling experienced by the audience; corrective action, trying to restoring the situation to the state of affairs before the objectionable action and 
or promising to 'mend one's ways' and make changes to prevent the recurrence of the undesirable act; and finally mortifications, where the accused may admit responsibility for the wrongful act and ask for forgiveness. Benoit uses the expression mortification from Burke (1970) in order to identify a particular form of confession and public petition for pardon.

Despite of Benoit's theory, we have to take in consideration other works in order to complete the sphere. Benoit talks about this strategies but he doesn't make differences between the political and the corporate communication.

Focusing on apologies in political communication, Abadi (1990: 470) provides a model by which we can differentiate between different ways of accountability: e.g., the acknowledgement of full or partial responsibility, with or without renunciation, having or not a promise to refrain, an offer of amends, and finally by making an implicit or explicit apology.

Recently, in a very interesting work, Hansson (2015) talks about the different strategies of blame avoidance in government. He mentions shifting of responsibility, attacking an opponent's character to discredit her, misrepresenting an opponent's position, concluding that a proposition is true because many people believe so, providing false analogies, claiming that temporal sequence equals causality; and using unclear language. But Hansson (2015: 4) as well speaks about the appealing to an audience's feelings of compassion (argumentum ad misericordiam) in which we can include the forgiveness speech.

It's also interesting to think about the links between this strategies and leadership. According to Mills, the apology speech has emerged as confidence sign in order to recognize own mistakes. In this context, we might look to Mills (2001: 114) explanation of the new "culture of apology":

What makes this new culture of apology so significant is not, however just the governments and institutions it involves but the change in sensibility it embodies. The new culture of apology reflects the emergence of a post-cold war era in which public discourse has increasingly taken on the ethics and informality for private discourse and produced a different set of expectations from those we are used to.

Apologies also have the ability to restore what we might call a communication initiative to the wrongdoer. By asking for forgiveness, the actor changes from a passive subject, who receives criticism for his/her acts, to an active subject, a person asking for forgiveness from the victim.

In this context, the victim has the chance to forgive (or not) the wrongdoer. It is especially interesting that there is a chance to go beyond the offensive act and restore the relationship between actors through communication. Once a person apologizes and the other forgives, we have a situation where actors must get over the offense; however, new issues to discuss may appear.

\section{Accounts of King Juan Carlos I}

As in every crisis managerial case, the first step should be a proper context analyses in order to determine what kind of image restoration strategy have to be developed. In 2012, Spain was a society where people were not used to listening to politicians apologizing. That's the reason why one of the most interesting cases we can analyse 
in Spain about political forgiveness are the accounts of King Juan Carlos I apologizing after an elephant hunt in Botswana. People perceived the king's travel to Botswana as inappropriate and the hunt was very criticised in a very hard moment for the Spanish economy. Here it's not important if the monarch was on his right or not. It's not a responsibility question. As Benoit (1995: 72) said, "The key point here, of course, is not whether in fact the actor caused the damage, but whether the relevant audience believes the actor to be the source of the reprehensive act". It's all about perceptions, not about facts, and in that moment, the people perceived that the elephant hunt was very inappropriate.

King Juan Carlos apologized after his discharge from the clinic where he was hospitalized for a hip surgery; the monarch spoke to a journalist and used the moment to apologize for the inappropriate hunt.

Before beginning, it is important to underline that this is a singular case. The case of King Juan Carlos should not be considered a speech asking for political forgiveness per se because his is not an elected position; nonetheless, we should recognize this speech because the King serves a public function as head of state, and his activities have public impact and repercussions. Hence, the former King's words provide an example of apologetic speech in Spanish politics. We will frame this speech within a broader context of events, following different theories about accounts and apology like the works of Benoit (1997), Schönbach (1980), or Abadi (1990).

King Juan Carlos was heavily criticised for going to hunt in a very sensitive moment. In 2012, Spain struggled with very high unemployment rates and cuts in public services. The latest news informed that total number of unemployed people rose in more than 4.5 million, its highest point at the time (El Mundo, 2012). The risk premium -an important marker in the cost of loans and borrowing by the private sector and government- was also in very high levels (413 points from the German Bund on the $18^{\text {th }}$ of April) and the government lead by Mariano Rajoy was carrying through several reforms, which resulted in increased social conflict.

About scandals, Thompson (2000: 245) said "scandals are battles for symbolic power where reputation and confidence are at stake" thus, the main challenge for the monarch -as head of state- was to keep the confidence.

In recent years, support for the Casa Real has dramatically dropped, as shown in Graphic $\mathrm{n}^{\circ} 1$, which displays the variation in monarchy valuation in the last few decades.

Graphic 1. Monarchy support evolution according to CIS.

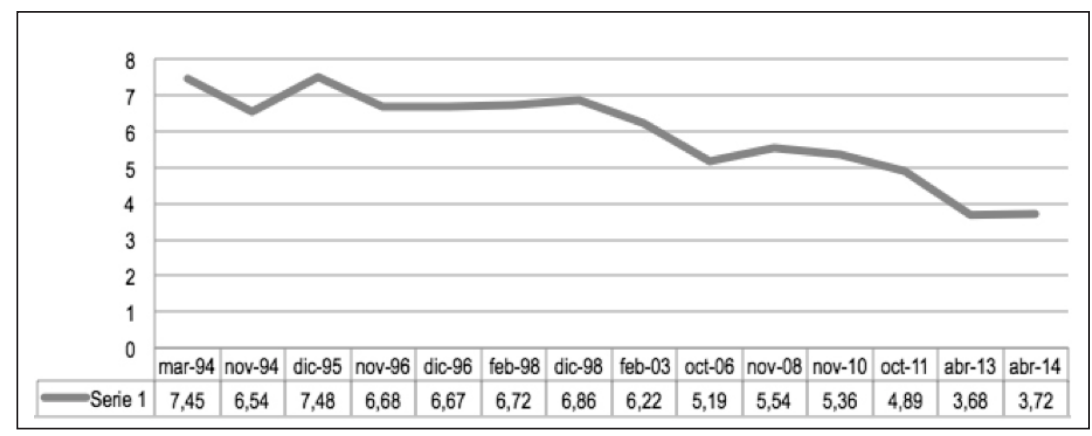

Own preparation based on CIS. 
On April 20,2012, the king leaves the clinic after a surgery because of a fall in the elephant hunt. The monarch apologizes when providing an answer to a question from Luis Lianez, the Spanish Television -TVE- journalist (Martínez-Fornés, 2012):

- Journalist: 'Your majesty. Good morning. How do you feel today?'

- King Juan Carlos: 'Much better. I thank the entire medical staff and the clinic, anyway... how they treated me. I'm wishing to retake my duty and... I'm so sorry. I was wrong and it will not happen again. And thank you for your interest during these days and for being here so long'.

Thus, afterwards the media fuss the King apologized to citizens. First of all, it's important to say that the King apologized personally. He didn't it through a press release or spokesperson, even though he could have done it that way. He stood in front of the cameras and said what he thought he had to say. The fact of doing it personally adds credibility because people could see him apologizing and he sent a message composed of verbal, nonverbal and paralinguistic components. This is far from a cold press release or a message from a spokesman. If that would have been the case, people could accuse him of hiding behind them and maybe this would have increased public criticism of the monarch. It's also interesting that the monarch did not read anything, no papers nor notes, witch adds spontaneity and sincerity to his words.

In this regard, Benoit (1997: 183) wonders if the accused person may always answer to the charges. He concludes that not necessarily. First of all, it's because is possible to redefine the attack. In second place, we can try to focus on other issues. And by last, it's possible that the accusation may not be important for the audience. But, as seen in this case, the king should consider that the accusation was hard enough.

It is important to think about changes in communication and leadership cultures in the recent past. A few decades ago, it would have been impossible to imagine a King having to apologize for a private act. The immunity that monarchies used to have gave them a higher status; however, nowadays this immunity is not enough to avoid negative critiques.

A quiet analysis of the king's intervention reveals that, first the monarch tried to give a positive message, ensuring that he felt better, and he also tried to be polite by expressing his gratitude to the medical staff for all of the attention received.

Other interesting field is the moment in witch he said this words. It's the first public apparition after his surgery and the first public declarations. As known, time control is very important in crisis management. The monarch uses his first public words to apologize and to show contrition. The order of the intervention is also important. The king expressed his desire to resume his duty, trying to clear up doubts about his physical condition to that. After this, he apologized. The monarch also shows his courtesy and interest with journalist, being kind and thankful for their interest and for being there for so long waiting for news.

The king speaks in a 'rushed' way, abusing of juxtaposition to join his phrases. From a non-verbal communication standpoint, the monarch uses a tone of voice that 
transmits some kind of vulnerability. He hangs his head right as the moment before giving his apology. After that, he looks again at the journalist who made the question. Manuel Jabois, El Mundo journalist said with regards to it:

The way of looking, which deviated before apologize, is a micro body-language treatise [...] The King ends his gratitude to hospital staff and deviates the eyes for an instant in what seems an enormous act of shame, the painful constriction imposed by unlucky circumstances (Jabois, 2012).

We can differentiate three phases in D. Juan Carlos' speech, which made his words a complete message: the apology, the explicit acknowledgement of the blame, and the amendment proposal.

- Apologize: "I am sorry". Perhaps these three words may have been enough. I'm sorry is indeed a more intense way to apologize but less than ask for forgiveness. "I'm sorry" means that the speaker understands and feels bad for what happened. According with Abadi (1990) we could consider that this can be an explicit expression of apology, which could include all of the previous states: acknowledging responsibility, renunciation of act, a promise to refrain from the act, and an offer of amends. According to Schönbach it can be considered a concession, and according to Benoit, mortification. The speaker admit responsibility for the wrongful act and ask for forgiveness.

- Explicit knowledge of the blame: "I was wrong". This phrase reinforces his guilty recognition. The monarch shows he understands his mistake and acknowledges his guilt. If we go back to Abadi's model, this would be the first step in his forgiveness speech.

- Amendment proposal: "It will not happen again". Here, he shows people that he will work to ensure that it will not occur again. Not only does he apologize and acknowledge the blame, but he added that he would not fail again with regards to not meeting the public's approval. If we go back again -for the last time- to Abadis's model, we can see that in this phrase he apologize explicit satisfying the third step: promise not to fail again. We may consider it as a promise for a corrective action as well.

If we take Benoit's model, the King develops mortification with an added corrective action. We find it in his promise that 'it will not happen again,' which reinforces his message. In this way, taking Schönbach's (1980) previous model, the monarch develops a combined apology in which he adds an expression of regret concerning own responsibility for the failure event and an offer - a promise in this case- of restitution or compensation Schönbach (1980: 196). 
According to Abadi (1990) we should understand that the monarch offers a global account through an explicit expression of apology. Nonetheless, we can consider that he did not achieve the next to last step, in which 'a promise to refrain from act' is offered. If we observe the beginning of the message, when he ensures that he's wishing to resume his role as monarch to retake his duty, despite of his physical condition, he is showing a positive attitude to try to refrain from act. That's why we can consider both options: as an incomplete account or a complete apology message.

\subsection{Public valuation}

After the monarch words, several media outlets published opinion polls about the affair. As we have limited ourselves in this investigation to two newspapers, we will take the results from an opinion poll published by El Mundo on the 22th April. The newspaper opened its edition with a title in three columns in which affirmed: "70\% forgives the king, but 52\% see his image damaged" (Prego, 2012).

The survey firm Sigma Dos developed the poll. The results are broken down into several categories. Of the interviewees, $72.4 \%$ responded positively $(52 \%)$ or very positively $(20.4 \%)$ to the question "What's your valuation about the apology from the King?" That means more than $70 \%$-almost three quarters- of the interviewees judge the accounts positively in the face of the $25.6 \%$ whom characterized the apology as mediocre (13.8\%), bad (8.7\%) or very bad (3.1\%) (Prego, 2012b).

Table 1. Answers for questions about the king's acts 1.

\begin{tabular}{|l|l|l|l|l|l|l|l|l|l|l|l|l|l|l|l|}
\hline In \% & \multicolumn{1}{l|}{ Sex } & \multicolumn{1}{l|}{ Age } & \multicolumn{1}{l|}{ Vote as remembered } & \multicolumn{3}{l|}{ Employment situation } \\
\hline & H & M & $18 / 29$ & $30 / 44$ & $45 / 64$ & +65 & PP & PSOE & IU & UPyD & Others & Employed & Unemployed & No act. \\
\hline Very well & 20,2 & 20,6 & 13,4 & 19,4 & 20,9 & 27,9 & 23,7 & 26,8 & 6,5 & 19,7 & 17,8 & 18,4 & 16,7 & 24,6 \\
\hline Well & 50,0 & 54,0 & 47,0 & 50,6 & 53,5 & 56,7 & 54,0 & 56,4 & 51,5 & 50,0 & 49,7 & 49,1 & 53,2 & 54,9 \\
\hline Not bad & 13,1 & 14,5 & 19,6 & 16,5 & 11,9 & 7,0 & 9,6 & 10,1 & 15,2 & 15,3 & 16,9 & 16,6 & 16,5 & 9,2 \\
\hline Bad & 10,4 & 7,1 & 15,2 & 8,5 & 8,1 & 3,9 & 9,3 & 3,6 & 12,8 & 15,0 & 9,5 & 9,9 & 9,5 & \\
\hline Very bad & 3,8 & 2,5 & 2,9 & 3,1 & 3,0 & 3,3 & 2,5 & 2,0 & 6,1 & & 3,7 & 3,8 & 1,5 & 3,0 \\
\hline NA & 2,6 & 1,3 & 1,8 & 1,9 & 2,5 & 1,2 & 0,9 & 1,0 & 8,1 & & 2,3 & 2,2 & 2,6 & 1,3 \\
\hline
\end{tabular}

The last question in the survey shows that people do not believe that the strategy has repaired the damage to the image of the Crown due to the Botswana trip. The survey reveals that $39.3 \%$ believe that the apology repaired the damage, while over half $(52.8 \%)$ believe that it does not.

With this answer, the interviewees probably show a certain degree of scepticism about the King's words. Perhaps they prefer to be prudent about possible unexpected relapses or hope that the king to fulfil his own promise "It will not happen again".

Thus, despite of 4 out of 10 people believing that the King's apology repaired the damage, in view of all these elements and previous questions, we can affirm that the monarch words establish a base to work in order to repair the image. 
Table 2. Answers for questions about the king's acts 2.

\begin{tabular}{|l|l|l|l|l|l|l|l|l|l|l|l|c|c|c|}
\hline In \% & \multicolumn{4}{l|}{ Sex } & \multicolumn{4}{l|}{ Age } & \multicolumn{4}{l|}{ Vote as remembered } & \multicolumn{4}{l|}{ Employment situation } \\
\hline & H & M & $18 / 29$ & $30 / 44$ & $45 / 64$ & +65 & PP & PSOE & IU & UPyD & Others & Employed & Unemployed & No act. \\
\hline Yes & 43,0 & 35,7 & 29,9 & 37,8 & 38,7 & 51,2 & 51,6 & 35,6 & 14,9 & 42,2 & 36,4 & 39,7 & 28,5 & 44,1 \\
\hline No & 49,8 & 55,8 & 67,0 & 53,0 & 54,6 & 36,7 & 42,3 & 58,6 & 82,4 & 57,8 & 53,3 & 54,5 & 61,6 & 46,6 \\
\hline NA & 7,2 & 8,6 & 3,0 & 9,2 & 6,7 & 12,1 & 6,1 & 5,8 & 2,7 & & 10,3 & 5,8 & 10,0 & 9,3 \\
\hline
\end{tabular}

The survey's data sheet is similar to the main opinion polls done in Spain (Prego, 2012b): Universal, older than 18 years old. National field. Sample: 1.000 interviews with error margin of $\pm 3.16 \%$ with a level of confidence of $95.5 \%$ (Sigma two) and $\mathrm{p} /$ $\mathrm{q}=50 / 50$. Multistage, stratified and random sample. Telephonic interview. Performed between $19^{\text {th }}$ and $20^{\text {th }}$ April 2012, the two days following the monarch's words.

Despite this, it doesn't clear up some questions as to the King's valuation amongst younger sections (16-18 years). This could be interesting because the valuation is more negative among younger interviewees. Nonetheless, as said, we can affirm that the valuation about the King's apology was overall positive, even amongst traditionally critical groups such as Izquierda Unida (United Left) voters, of whom 58\% consider that the monarch did well or very well by apologizing and $46 \%$ say that they would forgive him.

\subsection{Qualitative impact}

There is a widespread agreement in both medias about the King's act. The editorials and columnists valuate it as positive.

The same Thursday $19^{\text {th }}$ April, on its editorial, El País describes it as "unprecedented gesture" and adds that it is about an act "that honours him" (El País, 2012). The following Sunday, professor of the Universidad Nacional de Educación a Distancia (UNED), Santos Juliá (2012) shared the same though on his column titled "Something more than a mistake". Meanwhile, El Mundo, on his $19^{\text {th }}$ April front page already affirmed, "Yesterday in a historic day for the Spanish monarchy, the royal forgiveness focused the attention" (Romero, 2012). The same newspaper, the same day on its editorial titled "Apologizing, a gesture which honours the king" argues "The king understood that the travel was a mistake and recognised he was wrong" and address about the already commented links about apologizing and religion: "[...] no lack in his attitude none of the five elements that the Catechism attributed to this sacrament: the examination of conscience, repentance, the purpose of the amendment, saying sins to the confessor and the fulfilment of penance". According to this media, the forgiveness, "it highlights that D. Juan Carlos has enough common sense to understand when he had mistaken, despite of lapdog's voices" (El Mundo, 2012b). Hence the newspaper links the monarch's words with the common sense and values them positively.

In a brief review through some reporters and opinion leaders words in both medias, we found positive widespread opinions about monarch message. In El Mundo, Manuel Jabois (2012) titles: "The humble king" and comments "yesterday, the king acknowledged with greatness blame noted by others and which he is still looking for 
[...]". The El País reporter, Mábel Galaz claims that correction acts are unusual in monarchs but: "sometimes, depends on them their connection with people (Galaz, 2012)" in allusion to the apologize words. Also in El País , the writer David Trueba, in his column affirms that Spain is a country "where no one apologizes, not even whom kicks in his neighbour's eye (sic)" and adds that the King's act sets a precedent (Trueba, 2012). The professor of the Universidad Complutense, Antonio Elorza comments, as well in the PRISA group newspaper:

The responsibilities are not specified, and intelligently, any mention to royal dignity is avoided, which would create a distance impression, and as a result favoured the refusal in the target of the message (Elorza, 2012).

There were some opinions against the king as well, although fewer. The writer and columnist Maruja Torres said: "If hunting should disappear in Neolithic, the Monarchy should disappear now. We will do everything possible" (Torres, 2012). Also Almudena Grandes (2012), who days later since the royal apologia affirmed in her column that the king's hunt have been deplorable (sic) and: "the one method of viable democratization for a monarchy is its disappearance. And there is the truthful gravity of this crisis". But as said, the number of this kind of criticism was fewer than the positive ones in selected medias.

But beyond the published opinion in the main medias, it was a very significant act. As said, in 2012, Spain was a society where people were not used to listening to politicians apologizing. Two years later, during October 2014, three of the most important Spanish leaders: Mariano Rajoy, Esperanza Aguirre -from Partido Popular-and Pedro Sánchez, the new leader of the PSOE apologized for several corruption issues.

Sanchez was the first leader in apologize, he made it asked by a journalist about the corruption during a tv interview in a morning magazine. 'I apologize to the public because there are socialist party militants who have committed this type of 'Shameless' (sic.)'

After a very important operation against corruption in 2014 witch Partido Popular was involved in, the regional leader Esperanza Aguirre also apologized in a press conference 'I want to apologize to all the Madrilenians for this mistake in the same way that I want to apologize to all the militants, those thousands of honest and sacrificed militants of the Partido Popular of Madrid. I want to tell them sorry by proposing them this man as secretary general'. She made reference to one of the main suspicious of the operation, Francisco Granados.

The following day, the prime minister (and Partido Popular leader), Mariano Rajoy apologized in the upper house about corruption cases with the following words 'I apologize to all Spaniards for having placed in positions to unworthy people'.

The words of all of them were clear and convincing. They didn't use other image restoration strategy but mortification. They ask for forgiveness by their responsibility as party leaders for the designation of unworthy people.

Obviously, we cannot say that there is a direct influence between the king's words in 2012 and the strategy of these leaders in order to try to restore their images. But 
it's important to know that they did it in a context where previously it would be rare. Up to this moment, instead of apologize for mistakes, in politics was more common to deny or justify, resources that we can consider as aggravating (Hodgins y Liebeskind, 2003: 312).

\section{Discussion}

The survey published in El Mundo and used in this work in order to illustrate de public valuation, can't be taken as concluding. Nonetheless, taking into account the information displayed by Sigma Dos for El Mundo, we can consider that the king's strategy to manage the crisis was accurate. The interviewees valuate it positively and considered to forgive the king. Despite this, it's important to remember that interviewees did not consider that the king's apology restored the crown image. It could be because the crown image deterioration process started before the Botswana issue.

Nevertheless, despite the widespread positive valuation in content of medias about the King's words, as seen in the editorial analysis in both El País and El Mun$d o$ the day after the apologize, we can not ignore that the medias excluded from this paper could have published critical information or columns with the monarch acts.

Later information demonstrates that the Casa Real management of this crisis did not improve the valuation of monarchy in public opinion. In fact it continues descending slowly but constantly, as shown in graphic number 1. From this standpoint, the editorial of El Mundo of $19^{\text {th }}$ April comments already:

It would be very cynical to declare that the Crown ends this incident enforced, but at least, the King have had the intelligence of redress, which says a lot on his favour to the extent that he knew to five preference to the institution instead of his pride.

It is important to remember that as Burns and Bruner (2000) said on their critic to Benoit, the reduction of spaces in medias and the informative interest for a new could have large causes: "newspaper coverage of an issue can decline for many reasons" (Burns and Bruner, 2000:35). Although the present paper maintains that the apologetic speech was one of them.

Hence, the King's words didn't help him to improve the Casa Real social valuation. As shown in graphic number one, the Botswana issue and the later apologize did not avoid the devaluation of monarchy valuation which, in deed made its historical minimum one year later, in April 2013, with a valuation of 3.68 out of 10 .

Nevertheless, the present analysis is more specific and is focused on the unusual crisis management developed by Casa Real. In this case, as shown and analysed in this paper, we can conclude that the King apology was positive from standpoint of seen information. It was useful in order to stop the criticism and to try to restore the king image after the hunt. 
According to Ware and Linkungel, "Every apologize, therefore, is in some sense unique" (1973: 274), so that we wanted to show our own vision of the King's apologies and its effects as communication strategy in order to preserve the crown image.

Despite we cannot consider the direct influence of the king's words in following cases of forgiveness speech in Spanish political leaders; we may pay attention in this sense because of the impact and good reactions caused by the monarch strategy to restore his image.

\section{Conclusions}

Forgiveness speech, mortification or guilty recognition may be an interesting strategy in order to restore a damaged image. It can help to fix communication relations between parts and it proves interest to keep confidence, respect and good manners.

We can draw some conclusions from the present work.

- $\quad$ This case means the first public apologetic speech from a head of state in Spain, what implies a great repercussion in the Spanish political context.

- Despite he couldn't do it, the monarch decided to apologize. The importance of the accusation and the impact in the audience could be the main causes.

- The king chose a good way to do it. It was his first public apparition, spoke directly to the camera and did not read any paper, which gave him spontaneity and credibility.

- Nowadays, as Mills (2001) suggested people demand a bigger accountability from their representatives. Transparency and exemplarity are demanded values in order to have a good valuation from citizens.

- Having in consideration all the elements with which we have worked, the forgiveness speech was a good strategy in order to stop the image damage.

- The way former king Juan Carlos apologized and the words he chose stopped the communication fuss against the crown and generated a good opinion according to published news in analysed medias. The king's speech meant a real turning point in order to change the public perception.

- $\quad$ The king had a considerable good reputation as head of state. In 2012, more than $70 \%$ considered a balance of kingdom as good $(52,5 \%)$ or very good $(23,9 \%)$ (Romero, 2014) which helped him in order to be trustworthy when he apologized.

As in most crisis managerial manuals, the monarch analysed the impact of the accusations and decided to develop a image restoration strategy. 


\section{References}

ABADI, A. (1990). The Speech act of apology in political life. Journal of Pragmatics $14,467-487$.

BENOIT, W. L. (1995) Accounts, excuses, and apologies: A theory of image restoration strategies. New York. SUNY Press.

BENOIT, W. L. (1997). Image repair discourse and crisis communication. Public Relations Review 23, 177-186

BURKE, K. (1970). The rethoric of religion. Berkeley, University of California Press.

BURNS, J., BRUNER, M. (2000). Revisiting the theory of image restoration strategies. Communication Quarterly 48, 27-39

GONZALES, M., PEDERSON, J., MANNING, D., WETTER, D. (1990). Pardon My Gaffe: Effects of Sex, Status, and Consequence Severity on Accounts. Journal of Personality and Social Psychology. 58 (4). 610-621

HANSSON, Sten. (2015). Discursive strategies of blame avoidance in government: A framework for analysis. Discourse \& Society. 26 (3) Pp. 1-26

HODGINS, Holley and LIEBESKIND, Elizabeth. (2003). Apology Versus Defense: Antecedents and Consequences. Journal of Experimental Social Psychology 39(4), 297-316.

KRUSE, N. W. (1977). Motivational factors in non-denial apología. Central states speech journal 28, 13-23.

MILLS, N. (2001). The New Culture of Apology. Dissent (Fall) 48(4), 113-116.

RYAN, H.R. (1982). Kategoria and Apogia: On Their Rhetorical Criticism as a Speech Set. Quarterly Journal of Speech 68, 256-261.

SCHLENKER, B. R. (1980), Impression management: the self concept, Social identity, and interpersonal relations. Monterey, CA: Brook/Cole.

SCHÖNBACH (1980). A category system for account phases. European Journal of Social Psychology 10, 195-200.

SCOTT, M. H., and LYMAN, S. M. (1968). Accounts. American sociological review, 33, pp 46-62.

SEMIN, G. R., and MANSTEAD, A. S. R. (1983). The accountability of conduct: a social psychological analysis. London: Academic Press.

SYKES, G. M., and MATZA, D. (1957) Techniques of neutralization: A theory of delinquency. American Sociological Review, 22. 664-670.

TEDESCHI, J. T., and REISS, M. (1981). Verbal strategies in impression management. In C. Antaki (Ed.), The Psychology of ordinary explanations of social behaviour (pp. 271-326). London: Academic Press.

THOMPSON, John B. (2000): Political Scandal. Power and Visibiliry in the Media Age, Oxford, Polity Press. [Ed. cast.: El escándalo político: poder y visibilidad en la era de los medios de comunicación, Barcelona, Paidós, 2000]

TUCKER, S. Et al. (2006) Apologies and Transformational Leadership. Journal of business ethics. 63 (2), 195-207

WARE, B . \& LINKUGEL, W. (1973) They spoke in defense of themselves: On the generic criticism of apología. Quarterly Journal of Speech 59, 273-283. 


\section{Newspaper References}

ABC, (2012). La humildad de un rey. ABC. $19^{\text {th }}$ April 2012 p. 1.

CUE, C. (2012). Horas difíciles. El País Domingo. Sunday 22 April 2012 p. 2.

EL MUNDO. (2012) El paro aumenta en 38.769 el primer mes de la reforma laboral. El Mundo. 3 April 2012. Avaible on: http://www.elmundo.es/elmundo/2012/04/03/economia/1333436711.html Accessed July 2014

EL MUNDO. (2012b) Pedir perdón, un gesto que honra al Rey. El Mundo. 19 ${ }^{\text {th }}$ April 2012 p. 2.

EL PAÍS. (2012). Gesto sin precedentes. El País. $19^{\text {th }}$ April 2012 p. 26.

ELORZA, A. (2012). El rey desnudo. El País. 21 $1^{\text {th }}$ April 2012 p. 18.

GALAZ, M. (2012). Un perdón poco usual el público. El País. $19^{\text {th }}$ April 2012 p. 11. GRANDES, A. (2012). Otra crisis. El País. $23^{\text {th }}$ April 2012 p.64.

JABOIS, M. (2012). El rey humilde. El Mundo. $19^{\text {th }}$ April 2012 p. 19.

JULIÁ, S. (2012). Algo más que un error. El País Domingo. $22^{\text {th }}$ April 2012 p.17.

MARTÍNEZ-FORNES, A. (2012). El rey: «Lo siento mucho. Me he equivocado. No volverá a ocurrir». $A B C 19^{\text {th }}$ April 2012. Avaible on http://www.abc.es/20120418/ espana/abci-salida-hospital-201204181233.html Accessed July2014

ORDAX, A. (2012). Patxi López cree que 'no estaría mal' que el rey pidiera disculpas por su viaje a Botsuana. Cadena SER. 16 ${ }^{\text {th }}$ April 2012. Accessed July 2014. Avaible on: http://www.cadenaser.com/espana/articulo/patxi-lopez-cree-estaria-mal-rey-pidiera-disculpas-viaje-botsuana/ csrcsrpor/20120416csrcsrnac_4/Tes

PREGO, V. (2012). El 70\% perdona al rey pero el 52\% ve dañada su imagen. El Mundo. $22^{\text {th }}$ April 2012. p. 1.

PREGO, V. (2012b). El rey recibe el perdón de los españoles. El Mundo. $22^{\text {th }}$ April 2012 p. 5.

ROMERO,A. (2012). Cuando reinar consiste en saber decir: "Lo siento". El Mundo $19^{\text {th }}$ April 2012 p. 1.

ROMERO,A. (2014). El apoyo a la monarquía sigue cayendo pero crece la valoración del Príncipe Felipe. El Mundo. $5^{\text {th }}$ January 2014. P.1.

TORRES, M. (2012). Ni uno más. El País. $19^{\text {th }}$ April 2012 p.56.

TRUEBA, D. (2012). Dogma. El País. $20^{\text {th }}$ April 2012 p. 57. 